\title{
Serum gold determinations in patients with rheumatoid arthritis receiving sodium aurothiomalate
}

\author{
J. D. JESSOP AND R. G. S. JOHNS \\ From the Department of Rheumatology, University Hospital of Wales, Heath Park, Cardiff, and the Clinical \\ Laboratories, The London Hospital
}

Despite numerous publications recording experiences using various gold salts for the treatment of patients with rheumatoid arthritis, there are relatively few reports concerned with the possible value of gold determinations in the management of patients on chrysotherapy.

Freyberg, Block, and Levey (1941), using a chemical method of analysis, studied the metabolism of different gold compounds in patients with rheumatoid arthritis. Subsequent studies failed to demonstrate any correlation between serum gold levels, response to therapy, or the development of toxicity (Freyberg, 1966). Smith, Peak, Kron, Hermann, Del Toro, and Goldman (1958), also using a chemical method of analysis, found that patients who developed a toxic reaction had a low urinary excretion of gold while those who failed to respond had a high rate. Lawrence (1961), using radioactive labelled sodium aurothiomalate, found no correlation between serum or urine gold levels and the therapeutic response in ten patients with rheumatoid arthritis.

Lorber, Cohen, Chang, and Anderson (1968) described a simple and accurate method for gold analysis in body fluids using an atomic absorption spectrophotometer. They determined the mean serum gold values in patients receiving weekly and monthly injections of sodium aurothiomalate (Myocrisin), and suggested that gold dosage should be adjusted to maintain the serum gold levels within a specified range above these mean values.

In an attempt to add further understanding to the place of serum gold determinations in the management of patients on chrysotherapy, we have estimated serum gold levels in patients with rheumatoid arthritis receiving injections of Myocrisin, and have correlated the results with the response to therapy and the development of toxicity.

\section{Material and methods}

33 patients were studied; all suffered from classical or definite rheumatoid arthritis (Ropes, Bennett, Cobb, Jacox, and Jessar, 1959) and all had active arthritis at the time of starting gold therapy. Rheumatoid nodules were present in six patients and radiological erosions in thirty. The functional capacity (Steinbrocker, Traeger, and Batterman, 1949) was impaired (Grade 2 or 3) in 26 patients.

Routine haematological measurements were performed by standard techniques (Dacie and Lewis, 1968). The mean erythrocyte sedimentation rate (ESR) at the time of starting gold was $56 \mathrm{~mm}$./1st hr (Westergren) (range 22 to 112). The haemoglobin, total and differential white cell count, and ESR were estimated before each gold injection. Tube latex tests were performed by a modification of the method of Singer and Plotz (1956) and were positive in 25 patients. Urine was tested for protein ('Albustix') before each injection.

Serum and urine gold estimations were made using an atomic absorption spectrophotometer (Pye Unicam Model SP 90) and the method described by Lorber, Cohen, Chang, and Anderson (1968). Recovery of gold added to serum or urine was essentially complete ( 95 to 102 per cent.). The coefficient of variation showing the reproducibility at various gold concentrations in test samples of gold added to serum is shown in Table I.

Table I Coefficient of variation at various concentrations of gold added to serum

\begin{tabular}{ll}
\hline$\mu g$. gold per. $100 \mathrm{ml}$. serum & $\begin{array}{c}\text { Coefficient of variation } \\
(\text { per cent. })\end{array}$ \\
20 & \pm 25 \\
100 & \pm 9 \\
400 & \pm 5 \\
\hline
\end{tabular}

Because of the marked variation in serum gold immediately after each injection (Figs 1 and 2), gold levels 
were estimated 7 days after each injection of Myocrisin while patients were still on weekly treatment. For the purpose of this study the serum gold level for each patient was taken as the mean of the number of readings available in patients on weekly gold who had reached a plateau after a total dose of $330 \mathrm{mg}$. Myocrisin (Fig. 3). The serum gold levels in patients receiving gold injections at fortnightly or monthly intervals later in the course of treatment are not included.

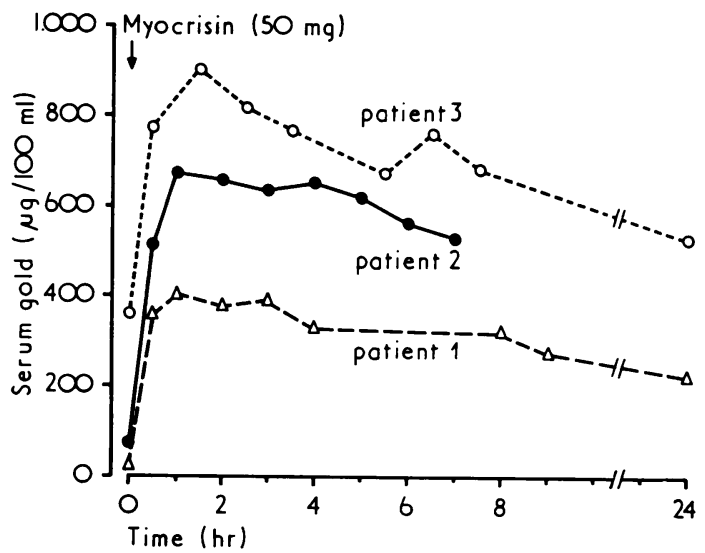

FIG. 1 Effect of a single injection of Myocrisin $50 \mathrm{mg}$. on serum gold levels in three patients (Cases $1,2,3$ ) with different total doses of gold. The peak level was reached 1 to 2 hrs after injection followed by a slow fall over the next 24 hrs

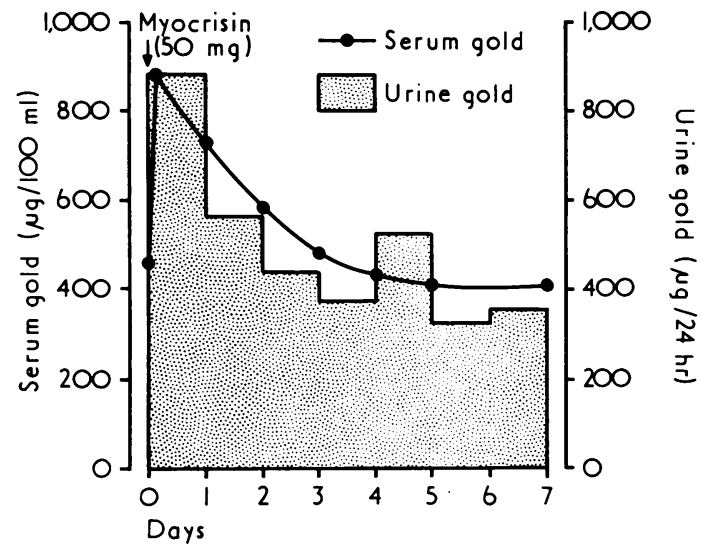

FIG. 2 Effect of a single injection of Myocrisin $50 \mathrm{mg}$. on serum and urine gold levels during the week after injection. This patient (Case 4) had already received $330 \mathrm{mg}$. Myocrisin and the serum gold levels had reached a plateau

\section{GOLD ADMINISTRATION}

After test doses of 10 and $20 \mathrm{mg}$. (and in the absence of signs or symptoms suggesting toxicity), Myocrisin was given by intramuscular injections of $50 \mathrm{mg}$. at weekly intervals. After a total dose of 400 to $500 \mathrm{mg}$. or more, depending on the therapeutic response, injections were given at intervals of 2 weeks and then 4 weeks indefinitely, provided an improvement was maintained.

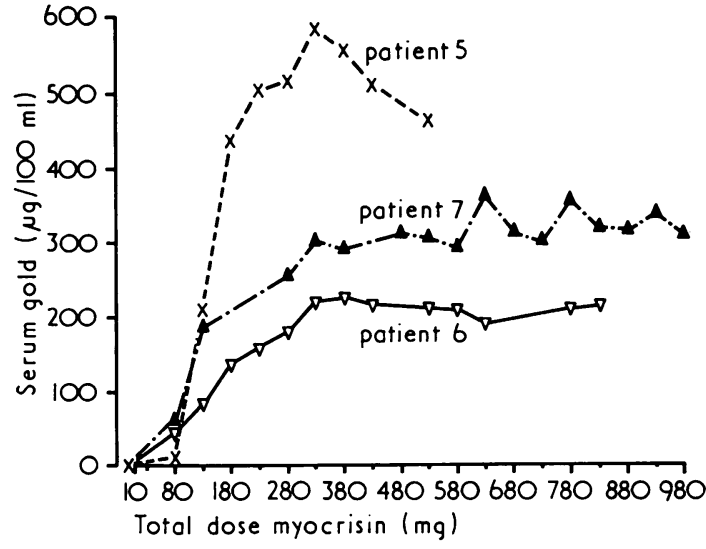

FIG. 3 Effect of Myocrisin injections given at weekly intervals in three patients (Cases $5,6,7)$ on chrysotherapy. Patient 5 developed serious skin toxicity after $580 \mathrm{mg}$. Myocrisin, but the serum gold levels were already higher than expected after $180 \mathrm{mg}$. Myocrisin

Patients were examined by one of us (J.D.J.) at regular intervals throughout the period of gold administration. Assessments were made of the number of painful joints on full range of active movement, duration of morning stiffness, and functional capacity. Peripheral joints tested for the presence of pain on full range of active movement included hands, wrists, elbows, shoulders, hips, knees, ankles, and toes, allowing a maximum score of 16 . The clinical and laboratory data available after approximately 1g. Myocrisin had been given were evaluated. In six patients gold treatment was stopped at a total dose of 480 to $700 \mathrm{mg}$. Myocrisin because of toxicity or obvious failure to respond. The major criterion for a clinical response to therapy was based on a 50 per cent. reduction in the number of painful joints on full range of active movement. Patients who showed an improvement in functional capacity by at least one grade, a 50 per cent. fall in the duration of morning stiffness, a 30 per cent. fall in $\mathrm{ESR}$, and a rise in haemoglobin of at least $0.5 \mathrm{~g}$. per cent. (mean of the last three determinations) were considered to have shown a beneficial response to therapy only if this was accompanied by a 50 per cent. reduction in the number of painful joints.

\section{Results}

To study the effect of a single injection of $50 \mathrm{mg}$. Myocrisin on serum gold levels over the next 24 hrs, preliminary investigations were performed on three patients (Cases 1, 2, and 3) who were starting gold treatment (Fig. 1). There was an immediate rapid rise in serum gold, reaching a peak 1 to $2 \mathrm{hrs}$ after injection, followed by a slow fall during the next 24 hrs. Serum gold levels were studied in a patient (Case 4) on weekly gold who had received a total dose of $330 \mathrm{mg}$. Myocrisin (Fig. 2). After the initial rapid rise, the serum gold levels fell slowly throughout the following week to approximately the pre-injection level. Urine gold excretion in this patient amounted to 14 per cent. of the injected dose of gold. 
The results of serum gold levels studied in three patients (Cases 5, 6, and 7) on weekly gold are shown in Fig. 3. In each case the serum gold level increased after each injection until a total dose of about $330 \mathrm{mg}$. had been given at which stage the levels tended to flatten out. The subsequent serum gold values for each patient remained reasonably constant, although the values for each individual differed considerably.

In view of these preliminary findings of a steady rise in serum gold level until a plateau is reached, the serum gold level for each patient was taken as the mean of the number of readings available in patients still on weekly gold who had reached a plateau after $330 \mathrm{mg}$. Myocrisin.

\section{CLINICAL RESPONSE}

A comparison of clinical and laboratory findings in all 33 patients with rheumatoid arthritis before and after treatment with Myocrisin is shown in Table II.

After gold therapy there was a highly significant reduction in the mean number of painful joints, a highly significant reduction in mean ESR, and a highly significant improvement in mean functional capacity grading. However, the reduction in duration of morning stiffness was significant only at the level $\mathbf{P}=0 \cdot 1-0 \cdot 2$. There was no change in mean haemoglobin levels.

21 patients (64 per cent.) had a good response to gold therapy judged by a 50 per cent. reduction in the number of painful joints. Of these 21 patients, only one failed to show a fall in ESR $>30$ per cent. and only two showed no improvement in functional capacity grading. However, of the twelve patients who did not have a 50 per cent. reduction in the number of painful joints, six had a fall in ESR $>30$ per cent. and two exhibited an improvement in functional capacity grading.

The 21 patients who gave a definite beneficial response to gold therapy had suffered from rheumatoid arthritis for a significantly shorter period than those who failed to respond, but there were no other differences between these groups before starting treatment (Table III). There was no significant difference in serum gold values between the patients who responded and those who failed to respond to gold (Table IV). A significant degree of correlating was found to exist between serum gold levels and the weight of the patient $(r=-0.37, \mathrm{P}=0.05-0.02)$.

Table IV Comparison of serum gold levels in patients with a good. doubtful, or poor response to gold

\begin{tabular}{|c|c|c|c|}
\hline Response to gold & Good & $\begin{array}{l}\text { Doubtful } \\
\text { or poor }\end{array}$ & $\begin{array}{l}\text { Significance } \\
\text { of difference } \\
\text { between } \\
\text { the means }\end{array}$ \\
\hline No. of patients & 21 & 12 & \\
\hline $\begin{array}{l}\text { Serum gold } \\
(\mu \mathrm{g} . / 100 \mathrm{ml} .) \\
\text { Mean } \pm \text { s.e. }\end{array}$ & $311 \pm 19$ & $326 \pm 29$ & NS \\
\hline
\end{tabular}

\section{TOXICITY}

Thirteen patients (39 per cent.) were considered to have signs and symptoms attributed to gold toxicity and analysis of these patients is shown in Table $\mathrm{V}$ (opposite). One patient had evidence of both skin and bone marrow toxicity.

Table II Comparison of various clinical and laboratory findings in 33 patients before and after treatment with sodium aurothiomalate

\begin{tabular}{|c|c|c|c|}
\hline $\begin{array}{l}\text { Clinical or laboratory } \\
\text { finding }\end{array}$ & $\begin{array}{l}\text { Before treatment } \\
(\text { Mean } \pm \text { s.e. })\end{array}$ & $\begin{array}{l}\text { After treatment } \\
(\text { Mean } \pm \text { s.e. })\end{array}$ & $\begin{array}{l}\text { Significance of } \\
\text { difference between } \\
\text { means }\end{array}$ \\
\hline $\begin{array}{l}\text { Number of painful joints } \\
\text { Sedimentation rate (ESR) } \\
\text { Functional capacity (Grade I to IV) } \\
\text { Morning stiffness (hrs) } \\
\text { Haemoglobin (g. per cent.) }\end{array}$ & $\begin{array}{r}7 \cdot 4 \pm 0 \cdot 6 \\
57 \cdot 0 \pm 4 \cdot 0 \\
1 \cdot 9 \pm 0 \cdot 1 \\
3 \cdot 0 \pm 1 \cdot 1 \\
12 \cdot 2 \pm 0 \cdot 2\end{array}$ & $\begin{array}{r}3 \cdot 6 \pm 0 \cdot 8 \\
33 \cdot 0 \pm 4 \cdot 0 \\
1 \cdot 4 \pm 0 \cdot 1 \\
1 \cdot 1 \pm 0 \cdot 8 \\
12 \cdot 4 \pm 0 \cdot 2\end{array}$ & $\begin{array}{l}\mathbf{P}=<0 \cdot 001 \\
\mathbf{P}=<0 \cdot 001 \\
\mathbf{P}=<0 \cdot 001 \\
\mathbf{P}=0 \cdot 1-0.2 \\
\text { NS }\end{array}$ \\
\hline
\end{tabular}

Table III Differences before starting treatment between clinical and laboratory findings in patients who subsequently showed or did not show a beneficial response to gold

\begin{tabular}{|c|c|c|c|}
\hline $\begin{array}{l}\text { Clinical or laboratory finding } \\
\text { under comparison }\end{array}$ & $\begin{array}{l}\text { Patients responding } \\
\text { to gold therapy }(21) \\
(\text { Mean } \pm \text { s.e. })\end{array}$ & $\begin{array}{l}\text { Patients not } \\
\text { responding to gold } \\
\text { therapy (12) } \\
(\text { Mean } \pm \text { S.e. })\end{array}$ & $\begin{array}{l}\text { Significance of } \\
\text { difference between } \\
\text { means }\end{array}$ \\
\hline $\begin{array}{l}\text { Duration of rheumatoid arthritis (yrs) } \\
\text { Number of painful joints } \\
\text { Sedimentation rate (ESR) } \\
\text { Duration of morning stiffness (hrs) } \\
\text { Haemoglobin (g. per cent.) } \\
\text { Functional capacity (Grade I-IV) }\end{array}$ & $\begin{aligned} 4 \cdot 6 & \pm 1 \cdot 0 \\
7 \cdot 0 & \pm 1 \\
56 \cdot 0 & \pm 6 \\
3 \cdot 4 & \pm 1 \cdot 0 \\
11 \cdot 9 & \pm 0 \cdot 2 \\
1 \cdot 8 & \pm 0 \cdot 1\end{aligned}$ & $\begin{aligned} 10 \cdot 1 & \pm 2 \cdot 4 \\
9 \cdot 0 & \pm 1 \\
57 \cdot 0 & \pm 3 \\
3 \cdot 4 & \pm 1 \cdot 0 \\
12 \cdot 6 & \pm 0 \cdot 3 \\
2 \cdot 2 & \pm 0 \cdot 2\end{aligned}$ & $\begin{array}{c}P=<0 \cdot 05 \\
\text { NS } \\
\text { NS } \\
\text { NS } \\
\text { NS } \\
\text { NS }\end{array}$ \\
\hline
\end{tabular}


Table V Comparison of serum gold levels in rheumatoid patients with and without evidence of gold toxicity

\begin{tabular}{|c|c|c|c|}
\hline $\begin{array}{l}\text { Toxic } \\
\text { reaction }\end{array}$ & $\begin{array}{l}\text { Number } \\
\text { in } \\
\text { group }\end{array}$ & $\begin{array}{l}\text { Serum gold } \\
\text { ( } \mu \text { g. per } \\
\text { cent.) } \\
\text { Mean } \pm \text { s.e. }\end{array}$ & $\begin{array}{l}\text { Significance } \\
\text { of difference } \\
\text { between } \\
\text { means }\end{array}$ \\
\hline $\begin{array}{l}\text { Definite or probable } \\
\text { toxicity }\end{array}$ & 13 & $341 \pm 33$ & NS \\
\hline $\begin{array}{l}\text { Skin reactions } \\
\text { (definite and } \\
\text { probable) }\end{array}$ & 11 & $356 \pm 37$ & NS \\
\hline $\begin{array}{l}\text { Skin reactions severe } \\
\text { (gold therapy } \\
\text { stopped) }\end{array}$ & 5 & $460 \pm 19$ & $\mathbf{P}=<0.001$ \\
\hline $\begin{array}{l}\text { Haematological } \\
\text { Renal }\end{array}$ & $\begin{array}{l}2 \\
1\end{array}$ & $\begin{array}{l}294 \pm 64 \\
293 \pm \alpha\end{array}$ & $\begin{array}{l}\text { NS } \\
\text { NS }\end{array}$ \\
\hline None & 20 & $301 \pm 15$ & \\
\hline
\end{tabular}

The skin manifestations in eleven patients varied from mild transient pruritus to severe pruritus with a generalized erythematous eruption. In five patients with severe skin reactions gold injections were stopped permanently. The mean serum gold in this group was significantly higher than in the non-toxic group (Table V).

Of the two patients with haemological toxicity, one developed pancytopenia after $930 \mathrm{mg}$. Myocrisin and the other severe thrombocytopenia after $810 \mathrm{mg}$. Myocrisin. Serum gold values were not significantly elevated in this group compared with the non-toxic group and both patients eventually made a complete recovery.

One patient developed possible early gold nephropathy with proteinuria of $30 \mathrm{mg} . / 100 \mathrm{ml}$. after 530 mg. Myocrisin in the absence of any other possible cause. Gold was stopped but the proteinuria persisted for 4 weeks before finally clearing.

\section{Discussion}

The clinical and laboratory findings studied in 33 patients with rheumatoid arthritis show that 21 patients (64 per cent.) had a beneficial response to gold. The data also show that the only significant difference between the patients at the start of chrysotherapy was in the longer duration of arthritis in the patients not responding to treatment. This confirms the observation that gold salts are more likely to be effective if given early in the course of active rheumatoid disease (Freyberg, 1966).

It has previously been shown that serum gold levels follow a predictable pattern during the initiation of chrysotherapy, with a gradual rise followed after a few weeks by a plateau (Freyberg and others, 1941). Our results are in agreement with these findings and show the plateau effect after a total dose of about $330 \mathrm{mg}$. Myocrisin. However, considerable differences between the levels at which gold tended to level out were observed in individual patients. Analysis of our results showed that the mean serum gold levels of these plateaux did not reflect changes in painful joint scores.

Krusius, Markkannen, and Peltola (1970) studied plasma and urinary gold excretion in 25 patients with rheumatoid arthritis who were receiving chrysotherapy and also observed considerable differences in plasma gold concentrations in individual patients after $150 \mathrm{mg}$. Myocrisin, but found high plasma levels in those who subsequently responded and low plasma levels in those with a poor therapeutic response. Lorber and others (1968) suggested that a critical serum gold level of more than $300 \mu \mathrm{g} . / 100 \mathrm{ml}$. may be necessary before a therapeutic response could be anticipated and suggested adjusting the dosage of gold salts according to the serum gold level to provide more effective chrysotherapy. Our results are in agreement with the earlier reports of Freyberg (1966) and Lawrence (1961) and the more recent report of Gerber, Paulus, Bluestone, and Pearson (1972) that a good therapeutic response appears to be independent of serum gold values.

The difficulty of interpreting apparent toxic reactions in patients on gold was emphasized in the multicentre trial conducted by the Empire Rheumatism Council (1961), when it was shown that 16 per cent. of the control patients had symptoms attributed to toxicity. In our series, thirteen patients (39 per cent.) were considered to have shown a toxic reaction due to gold. Although the mean serum gold level in the five patients with severe skin reactions was significantly higher than in the non-toxic group (Table V), only two of these patients had gold levels $>500 \mathrm{ug}$. $/ 100 \mathrm{ml}$., while three patients who never developed complications had mean levels $>400$ ug. $/ 100 \mathrm{ml}$. A larger number of patients may significantly affect our results.

Krusius and others (1971) found the highest serum gold values in five patients who developed toxic reactions (unspecified). Pole, Balazs, and Maserai (1971) described the occurrence of dermatitis in one patient with a serum gold level of $420 \mu \mathrm{g} . / 100 \mathrm{ml}$. Rothermich, Bergen, and Philips (1967) found no correlation between serum gold and mucocutaneous reactions in three patients, and similarly Gerber and others (1972) found no correlation in four patients who developed dermatitis.

Eosinophilia ( $>400 /$ cu.mm.) may be a useful warning of impending toxicity especially with regard to the skin. All our five patients with severe skin reactions had an eosinophilia and this preceded the dermatitis in four. In only one patient did the eosinophil count exceed 1,000/cu.mm. However, twelve patients (60 per cent.) in the non-toxic group also had an eosinophilia at some time during chrysotherapy, and in three patients (15 per cent.) this exceeded $1,000 / \mathrm{cu} . \mathrm{mm}$. One patient had an eosinophilia of $950 /$ cu.mm. before starting gold. 
Eosinophilia occurring in rheumatoid arthritis has recently been investigated by Winchester, Koffler, Litwin, and Kunkel (1971). Its significance during gold therapy remains uncertain, but it is probably wise to withhold injections in the presence of a persistent and otherwise unexplained eosinophilia $>1,000 / \mathrm{cu} . \mathrm{mm}$. (Jessop, 1972).

One patient developed a possible gold nephropathy, but the serum gold level was within the range of the non-toxic group. The problem of gold nephropathy has been reviewed in detail by Silverberg, Kidd, Shnitka, and Ulan (1970), who found no significant alterations in serum or urine gold levels compared with patients without a nephropathy.

\section{Summary}

Serum gold levels have been studied in 33 patients with rheumatoid arthritis receiving treatment with sodium aurothiomalate. Gold estimations were performed using an atomic absorption spectrophotometer.

There was no correlation between serum gold and the response to therapy, but the groups of five patients with skin toxicity in whom gold was stopped per- manently had a significantly higher mean serum gold than the group without complications. However, the number of patients in this group is small and a larger group needs to be studied for confirmation of these data.

No significant correlations were noted in those with haematological or renal toxicity.

The results suggest that very high serum gold levels in individual patients, which may be apparent after the third or fourth injection of sodium aurothiomalate, may provide warning of impending skin toxicity. Otherwise, serum gold estimations do not appear to be a useful measurement during treatment with chrysotherapy.

We thank Dr. Michael Mason, Dr. H. L. F. Currey, and Dr. C. G. Barnes, Department of Rheumatology, The London Hospital, for permission to study their patients and for their help and advice throughout the preparation of this paper. We thank Dr. B. Vernon-Roberts for statistical advice, Miss. D. Hayes (Superintendent Physiotherapist) and her staff for organizing gold clinics, and Mrs. E. Bolderston for secretarial assistance.

We are grateful to the Arthritis and Rheumatism Council and to May and Baker Ltd. for financial support.

\section{References}

DACIE, J. V. AND LewIS, S. M. (1968) 'Practical Haematology', 4th ed. Churchill, London

Empire Rheumatism Council (1961) Ann. rheum. Dis., 20, 315 (Gold therapy in Rheumatoid Arthritis: Final report of a multi-centre controlled trial)

FreYberG, R. H. (1966) 'Gold therapy for rheumatoid arthritis', in 'Arthritis and Allied Conditions', ed. J. L. Hollander, 7th ed., p. 322. Lea and Febiger, Philadelphia

- BLOCK, W. D., AND LEVEY, S. (1941) J. clin. Invest. 20, 401 (Metabolism, toxicity, and manner of action of gold compounds used in treatment of arthritis: Human plasma and synovial fluid concentrations and urinary excretion of gold during and following treatment with gold sodium thiomalate, gold sodium thiosulphate and colloidal gold sulphide)

Gerber, R. C., Paulus, H. E., Bluestone, R., and Pearson C. M. (1972) Ann. rheum. Dis., 31, 308 (Clinical response and serum gold levels in chrysotherapy)

Jessop, J. D. (1972) Practitioner, 208, 28 (The present status of chrysotherapy)

Krusius, F. E., Markkanen, A. and Peltola, P. (1970) Ann. rheum. Dis., 29, 232 (Plasma levels and urinary excretion of gold during routine treatment of rheumatoid arthritis)

LAWRENCE, J. S. (1961) Ibid., 20, 341 (Studies with radioactive gold)

Lorber, A., Cohen, R. L., Chang, Chia Chin, AND Anderson H. E. (1968) Arthr. and Rheum., 11, 170 (Gold determination in biological fluids by atomic absorption spectrophotometry: application to chrysotherapy in rheumatoid arthritis patients)

Pole, D. J., Balazs, N. D. H., AND Maserai, J. (1971) Med. J. Aust., 2, 1181 (Plasma gold estimations in patients receiving chrysotherapy for rheumatoid arthritis)

Ropes, M. W., Bennett, G. A., CoBb, S., JACOX, R., AND Jessar, R. A. (1959) Ann. rheum. Dis., 18, 49 (Revision of diagnostic criteria for rheumatoid arthritis)

Rothermich, N. O., Bergen, W., AND Philips, V. K. (1967) Arthr. and Rheum., 10, 308 (The use of plasma gold levels in determining dose, frequency, type of gold salt, and impending toxicity in chrysotherapy for rheumatoid arthritis)

Silverberg, D. S., KidD, E. G., ShNitKa, T. K., AND UlaN, R. A. (1970) Ibid., 13, 812 (Gold nephropathy. A clinical and pathologic study)

Singer, J. M., AND Plotz, C. M. (1956) Amer.J. Med., 21, 888 (The latex-fixation test. I. Application to the serologic diagnosis of rheumatoid arthritis)

Smith, R. T., Peak, W. P., Kron, K. M., Hermann, I. F., Del Toro, R. A., and Goldman, M. (1958) J. Amer. med. Ass., 167, 1197 (Increasing the effectiveness of gold therapy in rheumatoid arthritis)

Steinbrocker, O., Traeger, C. H., AND BatTerman, R. C. (1949) Ibid., 140, 659 (Therapeutic criteria in rheumatoid arthritis)

Winchester, R. J., Koffler, D., Litwin, S. D., AND Kunkel, H. G. (1971) Arthr. and Rheum., 14, 650 (Observations on the eosinophilia of certain patients with rheumatoid arthritis) 